\title{
The Recent Challenges of Globalization and the Role of Employee Engagement - The Case of Vietnam
}

\author{
Dr. Eswaranathan Ehambaranathan \\ Director of Studies, Royal Business College \\ Hastings, New Zealand \\ Ayesha Samie \\ Lecturer, RMIT International University \\ Ho Chi Minh City, Vietnam \\ Shagesheela Murugasu \\ Lecturer, Linton University College \\ Mantin, Malaysia
}

Doi:10.5296/ijhrs.v5i1.6896

URL: http://dx.doi.org/10.5296/ijhrs.v5i1.6896

\begin{abstract}
Over the recent years, changes in the human resources practice have led to a situation whereby the failure of some firms are due to the mismanagement of people rather than problems related to technical systems. Evidently, there have been also suggestions that the changes in employee engagement practices have not been corresponding with the changes that is taking place in the international business environment. As a result, organizations have achieved a relatively low level of effectiveness in implementing effective employee engagement practices. This is particularly the case in emerging economies such as Vietnam, a country exposed to challenges and opportunities of globalization. Therefore, in order to strive competitively in this period of globalization, managers must possess relevant competencies for effective implementation in the employee engagement policies and practices. Thus, this paper explores the competency-based research framework and draws implications from the employee engagement practice to prepare organizations in Vietnam for the challenges in globalization.
\end{abstract}

Keywords: Employee Engagement; globalization; Vietnam.

\section{Introduction}

Many economists considered the recent financial crisis; the late 2000s financial crisis as the worst financial crisis. Many argued that this financial crisis was the worst since the great depression of the 1930s. This financial crisis was also known as the Credit Crunch or Global Financial Crisis. This crisis led to the collapse of large financial institutions, the bailout of 
banks by national governments, and downturns in the stock markets in many countries such as Europe and the United States. Around the globe, the crisis inevitability brought to the failure of key businesses and a huge decline in consumer wealth and the economic activity. The macroeconomic aspects have been primarily focused by most of the researchers in respond to the financial crisis. However, there was less focus on the role of the employee engagement. Nevertheless, the developed economies such as Europe and North America have addressed predominantly in and with respect to the financial crisis. Ulrich (2006) stated studies on employee engagement are important as it analyses the positive value that enable organizations and nations to tune effectively in handling globalizations challenges.

Studies on the impact of the recent financial crisis towards Vietnam are limited. The recent financial crisis that hit Vietnam had brought a double effect on the commodity prices. By late 2008, Vietnam was seriously deteriorating in the macroeconomic and financial environment, with inflation levels above 20 percent producing ballooning trade and current account deficits as well as weak banking and financial sector. According to the UNDP (2010), current high inflation rates and unstable Vietnamese currency have led almost 60 percent of the Vietnamese population still to live with less than USD 2 income per day.

Despite the huge impact towards Vietnam, a quick literature review indicates that Vietnam is still under research. Literature search in various academic databases such as Proquest, Google Scholars and Emerald have shown that the research publications knowledge about Vietnam especially on the challenges of globalization and the role of employee engagement is limited. Almost there have been no academic papers published about Vietnam employee engagement role especially from the recent globalization perspectives. So, it is proven that an in-depth research needed and vital on the globalization challenges such as financial crisis and the role of employee engagement about Vietnam as it plays high importance towards her nation and society.

Thus, this paper explores the importance of human resources factor particularly the employee engagement in globalization. Next, Vietnam which is an emerging economy nation has been focused in respond to the recent globalization challenges from the employee engagement perspective. So, the objective of this paper is to present a conceptual framework for the employee engagement as a response to the growing interaction of globalization and business performance in Vietnam.

\section{Globalization and the Role Employee Engagement}

Globalization refers to the economic, social and cultural connectivity with people in other parts of the world (McShane \& Travagoline, 2007). An organization or nation globalize when they actively participate with other countries and culture. Fischer (2001) stated while organizations have operated across borders for more than two thousand years, the degree of globalization today is unprecedented because information technology and transportation systems allow a much more intense level of connectivity and interdependence around the planet.

Over the recent years, researchers around the globe have continued to debate if globalization 
improves the financial and social development of poorer nations. Globalization has indeed provided many organizations and nations with new markets and resources as well as broader net to attract valuable knowledge and skills. Nevertheless, globalization is often been criticized for its increasing competitive pressures and market volatility. It is true that many people from the developed nations are losing jobs and this is posing a problem for them since the business organizations are outsourcing jobs to other countries with a lower labour cost. On the other side, for nations that are at the receiver's end are also giving up the reins in the ends of a foreign company which might again lead to a sophisticated form of colonization (Neha, 2011).

However, it is an undeniable fact that the impact of globalization is visible and it largely affects the economy of the country. As most of the nations have started to practice an open door policy in their economy, the business organizations have shifted around its businesses freely. Riox, Bernthal \& Wellins (2011) stated that the top challenges of business organizations in today's world are the role of managers in coordinating activities in many different locations. Furthermore, multicultural teams and continual change of the globally competitive environment provides challenges towards managers to lead the team members. According to Neha (2011), it was suggested that employee engagement would be able to assist managers in overcoming global challenges. Similarly, McShane \& Travagoline (2007) stated that globalization affects workers as well as working conditions, labor relations, and corporate social responsibilities. They stated that the employee engagement is a human resource strategy which is adopted by many organizations to ensure the employees achieve a high productivity and morale.

Meanwhile, employee engagement is also known as work engagement or worker engagement and it is a business management concept. An "engaged employee" is one who is fully involved in, and enthusiastic about, his or her work, and thus will act in a way that furthers their organization's interests. Employee engagement is the extent to which workforce commitment, both emotional and intellectual, exists relatively to accomplishing the work, mission, and vision of the organization. Although the employee engagement term is commonly used by both practitioners and academic researchers, still it has ambiguities. The ambiguities begin at its true meaning and definition, and are continued to its 'cause and effect' relationship. Thus, it is important for an organization to understand the drivers of engagement (Robinson, Perryman \& Hayday, 2004).

Many researchers agree that defining employee engagement may not be simple. According to Gibbons (2007), the executives are beginning to realize that employee engagement does not mean the same thing to everyone in every company. He discovered that every representative in an organisation has different views and concepts of employee engagement. His arguments were proven to be true with his study on 17 employers. There was some confusion around the definition of employee engagement due to the number of consulting firms working in this area. However, researchers and opinion leaders provided the public with a basic definition of employee engagement which is the increased emotional and intellectual connection that an 
employee has towards their employer, supervisor and co-workers that result in an increased output of effort (Thompson, 2009).

Additionally, Dernovsek (2008) stated employee engagement is the involvement of employees with enthusiasm for work. Perrin Global Workforce Study (2003) explained that employees with the willingness and ability to help their company to be successful by largely providing discretionary effort on a sustainable basis are also called as employee engagement. According to Scarlett Surveys (2009), employee engagement is a measureable degree of an employee's positive or negative emotional attachment to their job, colleagues and organization which profoundly influences their willingness to learn and perform at work. Meanwhile, the institute for employment studies (2003) defined employee engagement as a positive attitude held by the employee towards the organization and its values. Thus, normally an engaged employee is aware of the business context, and works with colleagues to improve performances within the job for the benefit of the organization. So, the organization must work to develop and nurture engagement that requires a two-way relationship which is between the employer and employee.

Similarly, Khan (1990) stated that there are also various aspects of employee engagement which is from the physical, cognitive and emotional ways. It is also a connection to one's job or organization, attachments, commitments and organizational citizenship (Organ and Paine, 1999). Thus, based on the definitions of the existing literature review the employee engagement has its benefit towards organisations and it can be quoted here that employee engagement is distinctively different from satisfaction, motivation, culture, climate and opinion and it is very difficult to measure.

\section{Recent Challenges in Globalization and Employee Engagement Issues in Vietnam}

The recent globalization especially the global financial crisis had poses distinctive employee engagement challenges to businesses especially those operating across national boundaries as multinational or global enterprises. Gerard and Crim (2006) stated that employee engagement has been seen by many Asian multinational companies as a heightened level of ownership where each employee are encouraged to do whatever they can for the benefit of their internal and external customers as well as for the success of the organization. Many of these multinational companies believe that the role of employee engagement is crucial in retaining talent, reducing employees' turnover and improving employees' commitment, work productivity and quality (Gerard \& Crim, 2006).

Global business is characterized by the free flow of human and financial resources especially in the developing economies such as the Association of South East Asian Nations (ASEAN). These developments are opening up new markets in a way that has never been seen before. Vietnam as an example is a nation located strategically in the South East bordering China to the north, Laos and Cambodia to the west and South China Sea to the east. Geographic 
advantage and decades of hard work, commitment and continued reformation upon the launch of Doi Moi (meaning "reconstruction") programme by the Vietnamese Government since 1986, has transformed Vietnam into one of the most dynamic emerging markets in the world (Government Statistics Office, 2010). Vietnam's recent successive growth domestic product (GDP) has made her the second fastest growing economy in Asia after China. Vietnam is also one of the largest recipients of foreign direct investment (FDI) in the world, relative to the size of its GDP in recent years. According to the New York Times (2009), Vietnam has begun to surpass many of its neighboring countries. Vietnam is also currently Asia's second-fastest growing economy within 6 to 8 percent growth in recent years. The recent globalization of markets and production has brought Vietnam as a player into the new economy in the competitive world with positive growth annually. Thus, the rapid economy changes due to the recent globalization in Vietnam have been highly prioritized by the Vietnamese government. Additionally, the Vietnamese government is ensuring Vietnam to be remained as a developing nation and currently laying foundations in being an industrialized country by 2020 (Socio-Economic Development Plan, 2006).

Evidently, globalization and participation in ASEAN and WTO (World Trade Organization) has transformed Vietnam into a competitive nation economically in the region. However, to achieve a continuing economic growth, organizations require an understanding on the factors that can determine the effectiveness of various employee engagement practices and approaches. This can be important as countries normally have different dimensions which influence their attractiveness towards FDI. Moreover, these differences determine the economic viability of building an operation in a foreign country and that has been particularly a strong impact on the employee engagement in that operation.

Similarly the Vietnamese Government acknowledges that the current challenges faced by Vietnam are the lack of productivity, quality and innovativeness. According to Dr. Nguyen Thien Nhan, the Deputy Minister from the Education and Training Ministry (2007), the investors in Vietnam currently are very much focused on assembly-based and manufacturing industry. Almost all of these industries hire labor intensive which brings low value-added and low effectiveness to the nation. Most of these labors have less skills and only basic education requirement needed to perform their tasks. He explained further that the labor cost in Vietnam of making a shirt is about 1USD. However the same shirt is sold for 30 - 50 USD. The labor cost is only equals to $2-3 \%$ from the price of the shirt. Therefore, it is certainly ineffective for Vietnam in a long term to remain competitive in attracting foreign investors by just offering cheap labors. As such it can be stated that Vietnam is currently facing a huge problem in offering skilled workers in the market. A research needs to be conducted in addressing these issues and possible solutions especially on the Human Resources aspect needs to be identified in order for Vietnam to remain economically competitive in the market.

McBain (2007) analyzed the models that shows employee engagement is a function of or driven by, the human resource of an organization. According to McBain (2007), employee engagement is an integration of employee satisfaction, commitment and motivation with 
Human Resources Management (HRM). There are four factors that affect the HRM in global markets. The four factors identified are culture, economic system, political system and human capital (Noe, et al, 2000). Thus, consistent with the scope of this paper only human capital will be treated as the dimension of HRM in global markets. Bawa \& Ali (1999) explained that the human capitals are the skills, capabilities or competencies of the workforce. This is in consonance with the believe that competency-based human resource with effective employee engagement plans to provide a source for gaining competitive advantage and for countries profoundly affect a foreign country's desire to locate or enter that country's market (O'Reilly, 1992). So, this explains further why foreign firms locate and enter the local markets in Vietnam. Vietnam as a developing nation faces distinct globalization challenges. These challenges are addressed through a strategic approach towards the employee engagement practices.

The human resource profession worldwide has considered employee engagement as one of the key focus areas over the past few years. Ulrich (2004) stated that for the first time in the history of management, it is the human mind that is the primary creator of value. The quality of people and their engagement will be critical factors in corporate vitality and survival. Ulrich (2004) statement reflects the recent focus by human resource professionals and management towards employee engagement and its connection to sustainability and profitability. This new focus on employee engagement is driven by a labour shortage, which resulted in the need to attract and retain employees while continuing to improve performance and profitability.

Thompson (2009) also stated hiring top talent is one thing; keeping talent and getting its full engagement is another thing. According to the research done by Unlich (2004), 58 percent of the talented employees are mobile and always open to move to other organizations. Therefore, only employers that are able to engage employees are more likely to retain the same employees and increase their output and simultaneously increase the organisations outputs. Meanwhile, some human resource experts consider employee disengagement a significant contributor to poor corporate performance and profitability. Rampersad (2008) stated that lack of engagement is endemic and is causing large and small organizations all over the world to incur excess costs, under-perform critical tasks, and create widespread customer dissatisfaction.

Thus, extra costs and underperformance is a result of poor employee engagement that negatively affects the organization and over the long term it decreases profitability and results in poor sustainability. According to Gallup Management Journal (2005), a survey was conducted and found that almost 14 percent or 19.2 million of workers in United States who are 18 years old or older are actively disengaged. The survey results indicate that the lower productivity of disengagement of these workers cost the U.S. national economy about $\$ 300$ billion per annum. Thus, it is proven that the importance of employee engagement is because it connects towards the productivity of the organisation. More over, it is the productivity of the individual that affects the productivity of the organization and the overall financial 
performance and sustainability of the organization and nation in the long term.

\section{Managerial Competencies and Current Employee Engagement Status in Vietnam}

The idea that individual HR practices impacts the performance in an additive fashion (Delery \& Doty, 1996) is inconsistent with the emphasis on internal fit in the resource-based view of the firm. This idea, that a system of employment practices may be more than the sum of parts that appear to be consistent with discussions of synergy, configurations, contingency factors, external and internal fit as well as holistic approach (Delery \& Doty, 1996; Huselid, 1995). Meanwhile, Ulrich \& Yeung (1989) stated that the future professional will need four basic competencies to become partners in a strategic management process. These include business competence, professional and technical knowledge, integration competence and the ability to manage change. Furthermore, the United Kingdom-based Management Charter Initiative (MCI), an independent competence-based management development organization, identifies seven key roles and the required competencies. These include competencies required to manage roles like managing activities, resources, people, information, energy, quality and projects (MCI Management Standards, April, 1997). Thus, managerial competencies are vital in employing effective human resource activities in order to ensure the growth of business organizations. Similarly, Vietnam needs effective employee engagement strategies to face challenges and opportunities of globalization.

Meanwhile, Ruge (2011) stated that currently, employee engagement level in Vietnam is higher in the Asia Pacific Region, but the employees' intention to stay in the same company lower than other countries in the region. Based on the recent studies conducted Ruge (2011) states that Vietnam has currently recorded a 78 percent positive employee engagement. Meanwhile, on average the nations in Asia Pacific region recorded 74 percent. Thus, it is proven that Vietnam achieved better percentage than the average in the Asia Pacific region because of several reasons. Ruge (2011) claimed that top management's strategy and direction, employee's perception of the companies' image, effective performance evaluations, empowerment via an innovative climate and involvement in problem solving and increased sophistication in company systems and practices has led Vietnam to have better employee engagement rate those other countries in Asia Pacific region.

However, Ruge (2011) urged that in general, some areas of employee opinion in Vietnam have remained unstable over the 5-year period (2006 - 2010). Almost 54 percent employees in Vietnam on average are always seriously considering in leaving their current organization. Most of their negative comments are based on various subjects. Stress, balance and workload have been stated as one the dissatisfactions which includes excessive workload and job pressure. Meanwhile, less pay and rewards that does not match from the internal pay equity and performance also has created some discomfort among employees in Vietnam. Other dissatisfactions are such as poor benefits and abundant external job opportunities that are available in Vietnam. 
Thus, Ruge (2011) claimed that although employees' opinion on competitiveness in Vietnam is currently more positive and lesser than in the Asia Pacific Region which is at 61 percent, it is on a declining trend in the past 2 years. Evidently, GSO (2011) reported that Vietnam's overall competitiveness on quality of products, services and customer service has declined since 2007. Moreover, Vietnam is still lacking behind in innovation as the Vietnam development towards new products, services and responding to market changes are still poor and ineffective. Vietnam's Ministry of Education and Training (2011) also has reported that poor employee engagement has direct relationship with the current poor quality of services and organizations' in Vietnam.

\section{Framework and Propositions}

As a response to the employee engagement towards a growing interaction of globalization and business performance in Vietnam, a conceptual framework as illustrated in figure 1 has been designed. This framework consists of four variables which are the independent variables, intervening variables, dependent variable and moderating variables.

Based on the designed framework, the ultimate goal for most of the business organizations are to achieve high profits. Profits of the business organization normally are determined from the organizational performances. In the case of Vietnam, a competitive firm is been measured in various methods. The Socio-Economic Development Plan (2010) stated the Vietnamese Government has recently indicated that the tools of measurement of business organizations in Vietnam are based on the level of productivity, quality and innovativeness. The major weakness stated by the Socio-Economic Development Plan (2010) is that the business organizations in Vietnam posses' low productivity with low quality and poor innovation as most of these organizations have not obtained good policies in measuring internal and external forces. Thus, a solution which is the framework explains the importance of the internal and external forces towards achieving an effective organizational performance. The internal forces are the managerial competencies and employee engagement that lead organization performances. Alternatively, the external forces are the impact of globalization.

The managerial competencies are categorised as the independent variables in this framework. Competency is the ability for managers and leaders to direct work streams and define outcomes clearly. Competence refers to both the ability such as technical and non-technical ability. It should be noted that organization and personal managerial are much connected in the sense of personal core competencies and are said to be derived from the values and competencies of the organization (Reagan, 2004). Thus, without managerial competencies, it will be difficult to realise success. Although many incompetent teams are able to attract funding from various sources eventually a project will fail due to the shortcomings of the management team. Therefore, it is important to determine the current state of the management team and address shortfalls prior to undertaking a capital development. In this context, effective managerial competencies transform effective employee engagement. 
As been discussed in the literature review section employee engagement plays a dominant role in any organization. Employee engagement refers to how much employees identify with and are emotionally committed to their work. Commonly employees with a strong employee engagement are cognitive focused and possess the ability and resources to do so (McShane \& Travaglione, 2007). Thus, as the intervening variables, employee engagement can be executed effectively with the adequate support from the managerial competencies.

Meanwhile, with appropriate managerial competencies and effective employee engagement, organization would be able to face the moderating variables efficiently. Based on the framework, globalization such as competition and technology advancement would always posses a strong opportunity or threat to any nation. The proponents of globalization argue that it allows emerging countries such as Vietnam to develop economically and raise their standards of living. However, globalization can also be deeply controversial. The recent financial crisis has put globalization on hold with capital flows reversing and global trades shrinking. As a result, Vietnam that lies with a high influx of FDI would face a serious amount of challenges from globalization.

Overall, the following testable propositions are derived from the illustrated framework.

1. Managers must have achieved higher levels of managerial competencies to introduce and assist an effective employee engagement programs and activities in business organizations.

2. Managerial competencies are significantly related to organizational performance as it ensures an effective employee engagement processes

3. The extent of implementing on employee engagement practice contributes significantly to a firm's level of outcome.

4. The relationship between the employee engagement practices and organizational performance is affected by the globalization.

It may be pertinent to point out here that the four propositions derived from the framework is particularly relevant for giving insights into the employee engagement challenges faced by organizations in the new era globalization. In other words, these propositions will help us organize thoughts on the level of readiness of organizations in response to the challenges of the global business environment.

\section{Conclusions}

This paper sets out as a contribution to the current discourse on the interaction of globalization and the business performance especially with a flavor of the challenges from the perspectives of Vietnam. This paper presents a framework for employee engagement as a response to prepare organizations for the challenges of globalization. If the propositions outlined above are supported, then the real challenge for organizations in the era of globalization is to pay particular emphasis to strengthening their employee engagement by 


\section{Macrothink

upgrading the relevant competencies. The Vietnamese government and business organizations in Vietnam should brace up and have no choice but to develop and continuously upgrade the employee engagement and business competencies of their workforce. Addressing these issues is a necessary step towards facing the challenges of globalization in the next millennium. 
Figure 1

Theoretical Framework for Employee Engagement - The Case of Vietnam

Internal Forces

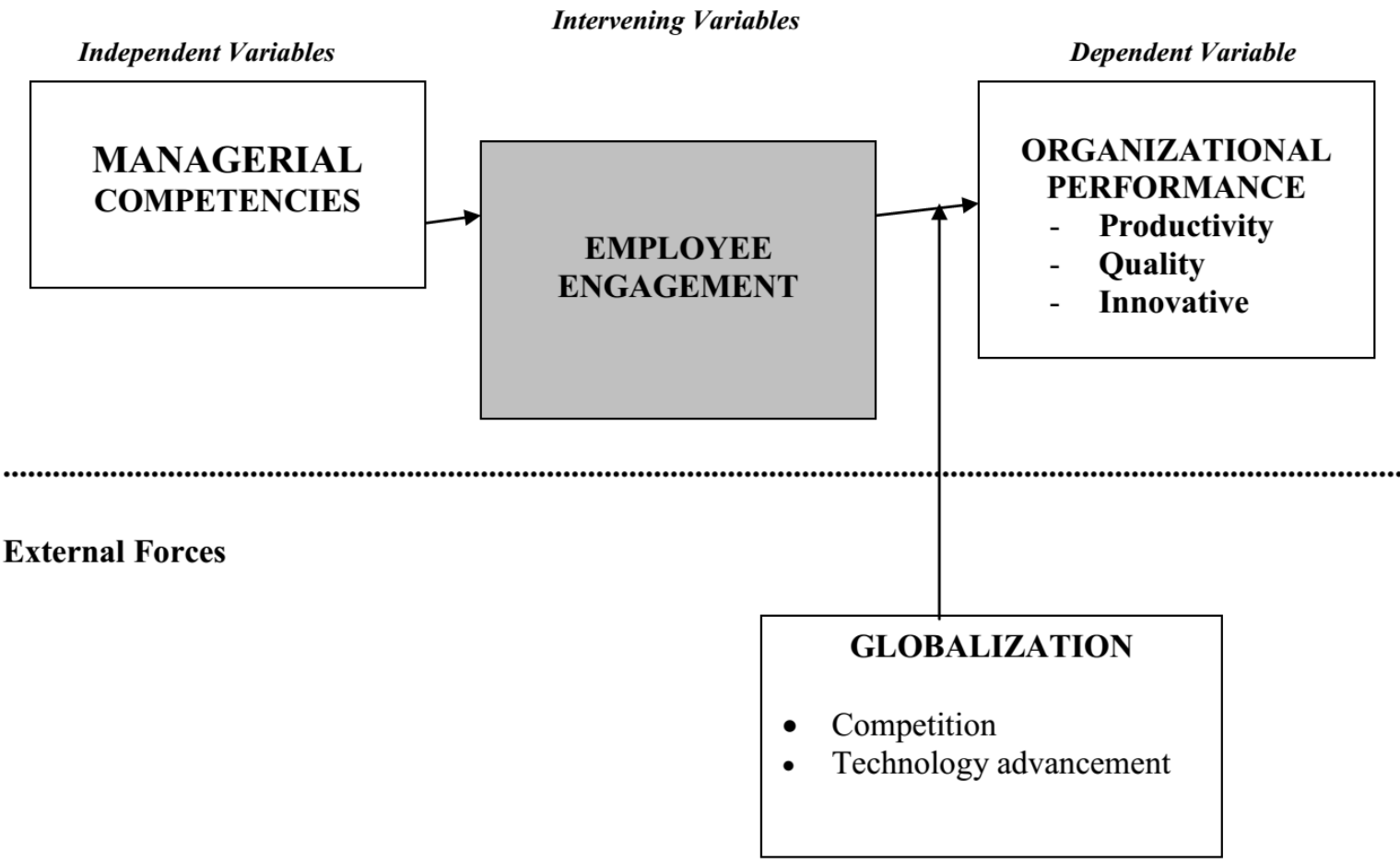

Moderating Variables 
References

2014, Vol. 5, No. 1

Abowd, J. M. 1990. Does performance-based co
Industrial and Labor Relations Review, 43: 52-73.

Arthur, J. B. 1994. Effects of human resource systems on manufacturing performance and turnover. Academy of Management Journal, 37: 670-687.

Barney, J. 1991. Firm resources and sustained competitive advantage. Journal of Management, 17: 99-120

Barney, J.B. \& Wright, P.M. 1988. On becoming a strategic partner: The role of human resources in gaining competitive advantage. Human Resource Management, 37(1): 31-46.

Baird, L \& Meshoulam, I. 1988. Managing the two fits of strategic human resource management. Academy of Management Review, 13:116-28

Cutcher-Gershenfeld, J. 1991. The impact on economic performance of a transformation in workplace relations. Industrial and Labor Relations Review, 44:241-60.

Delery, J. E \& Doty, D. H. 1996. Modes of theorizing in strategic human resource management: Tests of universalistic, contingency and configurational performance predictions. Academy of Management Journal, 39(4): 802-835.

Dernovsek, D .2008. Motivating and Retaining Top Talent through Employee Engagement. Academy of Management Journal, 12(4): 82-85

Dowling, P.J, Schuler, R.S \& Welch, D.E. 1994. International Dimensions of Human Resource Management. Belmont, CA: Wadsworth

Fisher, S 2001. Globalisation and its Challenges. American Economic Review, 1-29.

Gallup Management Journal. 2005. Employee Engagement in Business Organizations. Gallup Management Journal, 2- 15

General Statistics of Vietnam. 2010. Education, Health, Culture and Living Standard, Statistical Data, viewed 10 August 2011, 〈http://www.gSo.gov.vn〉

General Statistics of Vietnam 2010. Population and Employment, Statistical Data, viewed 18 August 2011, <http://www.gso.gov.vn>

Gerhart, B. \& Milkovich, G.T. 1990. Organizational differences in managerial compensation and financial performance. Academy of Management Journal, 33: 663-91 
Gerard, S. \& Crim, D. 2006. Employees attitude towards jobs. American Psychologist Association. 55: 68-78

Golden, K.A. \& Ramanujam, V. 1985. Between a dream and a nightmare: On the integration of human resource management and strategic business planning. Human Resource Management, 24(4): 429-452.

Greer, C.R. 1995. Strategy and Human Resources: A General Managerial Perspective. Englewood Cliffs, New Jersey: Prentice Hall

Hassan, S. M. J. 1992. Human Resource Management in a New Era of Globalism. Business Forum 17(1), Los Angeles, Winter: 56-66.

Huselid, M.A., Jackson, S.E \& Randall, R.S. 1997. Technical and strategic human resource management effectiveness as determinants of firm performance. Academy of Management Journal, 40(1): 171-188

Huselid, M. A. 1995. The impact of human resource management practices on turnover, productivity and corporate financial performance. Academy of Management Journal, 38: 635-672.

Huselid, M. A. \& Becker, B. E. 1996. Methodological issues in cross-sectional and panel estimates of the human resource-firm performance link. Industrial Relations, 35: 400-422.

Institute Employment Studies. 2003. Drivers of Employee Engagement. Institute Employment Studies. 22- 45

Irwin, J.G., Hoffman, J.J. \& Geiger, S.C. 1998. The effects of technological adaptation on organizational performance: Organizational size and environmental munificence as moderators. The International Journal of Organizational Analysis, 6(1): 50-64.

Jackson, S. E. \& Schuler, R. S. 1995. Understanding human resource management in the context of organizations and their environments. In M. R. Rosenszweig \& L.W. Porter (Eds.), Annual Review of Psychology, vol. 46: 237-264. Palo alto, CA: Annual Reviews.

Juhary Ali \& Bawa, M. A. 1999. Human Resource Management in the Context of Labor Market and Union Status: A Review. In Daing Nasir Ibrahim, Ishak Ismail, Mohamad Jantan, Yusserie Zainuddin and Zainal Ariffin Ahmad (Eds.), Reinventing Asian Management for Global Challenges, Proceedings of The third Asian Academy of Management Conference, 1999: 333-340.

Khan, W.A. 1990. Psychological Conditions of Personal Engagement and 
Disengagement at Work. Academy of Management Journal, 33(4), 692 2014, Vol. 5, No. 1

Kerr, J. L. \& Slocum, J. W. 1987. Linking reward systems and corporate cultures. Academy of Management Executive, 1(2): 99-108.

Lawler, E.E. III \& Mohrman, S.A. 1987. Unions and the new management. Academy of Management Executive, 1: 293-300

Leonard, J.S. 1990. Executive pay and firm performance. Industrial and Labor Relations Review, 43: 13-29.

MacDuffie, J.P. 1995. Human resource bundles and manufacturing performance: Organizational logic and flexible production systems in the world auto industry. Industrial and Labor Relations Review, 48: 197-221.

Majchrzak, A. 1988. The Human Side of Factory Automation. San Francisco: Jossey-Bass.

Management Charter Initiative (MCI). 1997. Mangement Standards. Management Charter Initiative (MCI), United Kingdom, April: Available at http://www.bbi.co.uk/whatis.html.

McBain. R. 1992. Employee Engagement. Journal of World Business. 22- 30

McShane, S \& Travaglione, T 2007. Organizational Behavior - On the Pacific Rim. McGraw Hill Australia.

Miles, R.E \& Snow, C. C. 1984. Designing strategic human resources systems. Organizational Dynamics, 16: 36-52

Ministry of Education and Training of Vietnam 2010, Education and Employment, viewed 18 July $2011,<$ en.moet.gov.vn>

Nambudiri, C. N. S. \& Saiyadain, M. S. 1978. Management problems and practices- India and Nigeria. Journal of World Business, Greenwich, Summer.

Nee, O.P. \& Khatri, N. 1999. Emerging strategic Human Resource Management issues in Singapore. In Daing Nasir Ibrahim, Ishak Ismail, Mohamad Jantan, Yusserie Zainuddin and Zainal Ariffin Ahmad (Eds.), Reinventing Asian Management for Global Challenges, Proceedings of The third Asian Academy of Management Conference, 1999: 311-320.

Neha. S (2011). Implications of Employee Engagement. Human Resource Management Journal. 
New York Times. 2005. Vietnam's roaring economy is set for world stage. New York Times, 2: $23-25$.

Ng, I. \& Maki, D. 1993. Human resource management in the Canadian manufacturing sector. The International Journal of Human Resource Management, 4: 897-916.

Noe, R. A., Hollenbeck, J. R., Gerhart, B. \& Wright, P. M. 1997. Human Resource Management: Gaining a Competitive Advantage., $2^{\text {nd }}$ Ed. Chicago: Irwin.

Noe, R. A., Hollenbeck, J. R., Gerhart, B. \& Wright, P. M. 2000. Human Resource Management: Gaining a Competitive Advantage, $3^{\text {rd }}$ Ed., Singapore: McGraw Hill.

O'Reilly. 1992. Differential Factors in Employee Engagement and Intent to Stay. Human Resource Management Journal. 1: 1-9

Oshionebo, M. E. 1992. New trends in Personnel Management: Quality of Worklife. Occasional Papers No. 20, Badagry, Lagos: Administrative Staff College of Nigeria (ASCON).

Osterman, P. 1987. Choice of employment systems in internal labor markets. Industrial Relations, 26: 46-67.

Ouchi, W. G. 1977. The relationship between organizational structure and organizational control. Administrative Science Quarterly, 22: 95-113.

Perrin Global Workforce Study. 2003. Winning Strategies of Workforce. Perrin Global Workforce.

Perryman, S. Hayday, S \& Robinson. D. 2007. The Drivers of Employee Engagement. Institute for Employment Studies,

Pfeffer, J. 1994. Competitive Advantage through People: Unleashing the Power of the Workforce. Boston: Harvard Business School Press.

Rampersad. H 2008. Why employees are not happy and engaged. Human Resource Management Journal.3: 2-8

Reagan, N. O. 2004. Overview of Employee Engagement. Organizational Dynamics, 24(5): 20-32

Ropo, A. 1993. Towards strategic human resource management: A pilot study in Finnish 
Power Industry Company. Personnel Review, 22(4): 35-53.

Ruge, B 2011. Employee Engagement \& Retention in Vietnam. American Chamber of Commerce, $1-15$.

Scarlet Survey. 2009. Quality Employee Engagement. Employee Engagement 2009. 2 -35

Schuler, R. S. 1992. Strategic human resource management: Linking people with the needs of the business. Organizational Dynamics, 21(1): 18-32.

Schuler, R. S., \& Jackson, S. E. 1987. Linking competitive strategies with human resource management practices. Academy of Management Executive, 1: 207-219.

Schuler, R. S., \& MacMillan, I. C. 1984. Gaining competitive advantage through human resource practices. Human Resource Management, 23: 241-255.

i.

Sims, R.S. \& Sims, S. J. 1995. Changes and Challenges for the Human Resource Professional. Personnel Psychology, 48(4): 965.

ii.

Snell, S. A. \& Dean, J. W. 1992. Integrated manufacturing and human resource management: A human capital perspective. Academy of Management Journal, 35(3): 467-470.

Socio-Economic Development Plan. 2006, SEDP Plan 2006 - 2010, SEDP, viewed 12 June 2011, <http://www.adb.org>

Socio-Economic Development Plan. 2010, SEDP Plan 2006 - 2010, SEDP, viewed 14 August 2011, 〈http://www.adb.org>

iii. Sonnenfeld, J.A. \& Peiperl, M.A. 1988. Staffing policy as a strategic response: A typology of career systems. Academy of Management Review 13: 588-600.

Terpstra, D.E. \& Rozell, E. J. 1993. The relationship of staffing practices to organizational level measures of performance. Personnel Psychology, (46): 27-48

Ulrich, D. 1996. Human Resource Champions. Boston: Harvard University Press.

Ulrich, D., Brockbank, W., Yeung, A. K. \& Lake, D. G. 1995. Human Resource Competencies: An empirical assessment. Human Resource Management, 34(4): 473-495.

Ulrich, D. \& Yeung, A. 1989. A Shared Mindset. Personnel Administrator, March: 117-134.

UNDP in Vietnam. 2010. UNDP Vietnam Population and Employment, viewed 18 August 2011, < http://www.undp.org.vn> 


\section{Macrothink

Vietnam Employee Engagement. Ministry of Education and Training viewed 18 May 2011, <http://www.en.moet.gov.vn>

Wagar, T. H. 1998. Determinants of human resource management practices in small firms: Some evidence from Atlantic Canada. Journal of Small Business Management, 36(2): 13-23.

Wright, P. M. \& McMahan, G. C. 1992. Theoretical perspectives for strategic human resource management. Journal of Management, 18 (2): 295-320. 